\title{
Prediksi Risiko Karies Baru Berdasarkan Konsumsi Pempek pada Anak Usia 11- 12 Tahun Di Palembang (Tinjauan dengan Cariogram)
}

\author{
Marlindayanti*, Sri Widiati**, dan Al Supartinah"** \\ *Politeknik Kesehatan Palembang \\ ${ }^{* *}$ Fakultas Kedokteran Gigi Universitas Gadjah Mada Yogyakarta \\ *Jl..Jend. Sudirman KM 3 No.1365 Palembang. Palembang, Provinsi Sumatera Selatan, Indonesia; e-mail: marlindayanti@ymail.com
}

\begin{abstract}
ABSTRAK
Penyakit rongga mulut yang sering diderita anak adalah karies gigi. Hasil penelitian terdahulu menunjukkan prevalensi karies gigi anak di Palembang sebesar 92,43\%. Pempek makanan khas jenis karbohidrat lengket yang dimakan bersama kuahnya (cuko), kebiasaan anak di Palembang mengkonsumsi pempek lebih dari 2 kali sehari. Frekuensi konsumsi karbohidrat yang sering berakibat karies gigi. Kebiasaan anak di Palembang mengkonsumsi pempek merupakan faktor risiko terjadinya karies gigi. Risiko karies gigi perlu diketahui untuk melihat kisaran karies baru yang dapat terjadi. Penelitian ini bertujuan memprediksi risiko terjadinya karies baru berdasarkan frekuensi konsumsi pempek di Palembang. Penelitian ini merupakan penelitian observasional dengan desain cross sectional. Pengambilan sampel menggunakan tekhnik cluster, subjek penelitian sebanyak 305 anak dari 52 SD di Palembang. Pengukuran prediksi risiko karies menggunakan cariogram dengan cara mengumpulkan data survei diet frekuensi konsumsi secara keseluruhan dan frekuensi konsumsi pempek, DMF-T, kapasitas buffer, sekresi saliva, plak skor, program fluor dan penyakit umum. Hasil penelitian menunjukkan prediksi risiko karies anak usia 11-12 tahun di Palembang 65,72\% (kategori tinggi) kontribusi pempek $45,83 \%$ dari total konsumsi makan keseluruhan. Peluang menghindari karies sebesar $34,28 \%$. Urutan penyebab risiko karies adalah kerentanan $(31,0 \%)$, pola makan $(17,36 \%)$, bakteri $(8,91 \%)$ dan keadaan lain yang berpengaruh $(5,35 \%)$. Kesimpulan penelitian, prediksi risiko terjadinya karies baru pada anak usia 11-12 tahun di Palembang termasuk kategori tinggi, pempek menyumbang $45,83 \%$ dari total konsumsi keseluruhan. Urutan prediksi risiko karies anak usia 11-12 tahun di Palembang, kerentanan, pola makan, bakteri dan faktor lain yang berpengaruh.

Maj Ked Gi. Desember 2014; 21(2): 117 - 121
\end{abstract}

Kata kunci: prediksi risiko karies, frekuensi konsumsi pempek, usia 11-12 tahun

\begin{abstract}
Prediction of The Risk Of New Caries Base on Pempek Consumption on Children Age 11-12 Years Old In Palembang. The oral cavity disease often suffered by children is dental caries. The previous research suggested that the prevalence of dental caries in Palembang was 92.43\%. Pempek is a typical type of carbohydrate food which is eaten together with its gravy (namely cuko). Children in Palembang usually consume the food more than twice a day. The high of frequently consumption of carbohydrate often can effect in dental caries. The risk of dental caries is necessary to investigate to predict the new caries incidence. This research is aimed at predicting the risk of new caries incidence based on the consumption frequency of pempek in Palembang. This research (study) used quantitative observational method with cross sectional design and cluster sampling technique. The subject study included 305 children selected from 52 elementary schools in Palembang. Cariogram model was applied to assess the prediction of the risk of caries by collecting data on diet survey, the overall frequency of pempek consumption, DMF-T, buffer capacity, secretion of saliva, plaque score, fluor program, and common diseases. The results showed that the risk of caries incidence in Palembang was $65.72 \%$ (high) while contribution of pempek was $45.83 \%$ out of the total food consumption. The chance of avoiding caries was $34.28 \%$. Meanwhile, the influential factors in dental caries were susceptibility (31.0\%), diet (17.36\%), bacteria (8.91\%), and other influential factors (5.35\%). This study suggested that the risk of new caries incidence in Palembang was categorized as high.Pempek contributed $45.83 \%$ of the overall food consumption. The sequence of factors influencing the risk of caries incidence in Palembang was susceptibility, diet pattern, bacteria, and other influential factors.
\end{abstract}

Maj Ked Gi. Desember 2014; 21(2): 117 - 121

Keywords: risk prediction caries, consumption frequency of pempek, aged 11-12 years

\section{PENDAHULUAN}

Kesehatan rongga mulut merupakan bagian dari kesehatan umum, walau demikian masih banyak masyarakat yang mengabaikan kesehatan rongga mulut terutama pada masa anak-anak. Salah satu penyakit gigi dan mulut yang sering dikeluhkan anak adalah karies. ${ }^{1}$ 
Karies merupakan penyakit yang menyerang jaringan keras gigi disebabkan oleh faktor internal (gigi, diet, bakteri, dan waktu) dan faktor eksternal (umur, sosial ekonomi, pengetahuan dan perilaku). ${ }^{2}$ Karies gigi diartikan suatu kerusakan jaringan keras gigi oleh asam karena proses fermentasi karbohidrat dalam waktu yang cukup lama ditandai proses demineralisasi jaringan keras kemudian diikuti kerusakan bahan organiknya. ${ }^{3}$

Anak-anak lebih menyukai dan sering mengkonsumsi makanan camilan, permen, minuman ringan yang sifatnya kariogenik. Pempek adalah makanan camilan dengan komposisi ikan segar, sagu, air, dan sedikit garam. Penyajiannya ada yang digoreng, direbus, dan dimakan bersama kuah asam manis atau pedas (cuko). Cuko merupakan hasil dari campuran air, gula merah, bawang putih, cabe rawit, ebi, asem jawa, dan sedikit garam yang dimasak dan diinapkan sampai terjadi fermentasi. Konsistensi pempek yang kenyal dapat menstimulasi sekresi saliva tetapi kandungan sagu yang sifatnya lengket memudahkan terbentuknya subtrat (plak). ${ }^{4}$ Substrat merupakan sisa makanan yang melekat pada gigi mengandung karbohidrat dan mudah difermentasi oleh bakteri Streptococcus mutan, hasil samping dari fermentasi adalah asam laktat yang menyebabkan proses demineralisasi. Fermentasi karbohidrat dipengaruhi oleh konsentrasi dan bentuk fisik makanan (bentuk cair, tepung, dan padat). ${ }^{5}$

Saat anak berumur 12 tahun gigi tetap sudah lengkap kecuali gigi molar ketiga, untuk itu WHO menetapkan usia tersebut sebagai global monitoring age untuk karies. Tahun 2003 WHO menetapkan acuan Global Goals for Oral Health 2020, dengan target meminimalkan dampak dari penyakit mulut dan kraniofasial, melalui upaya promotif dan mengurangi dampak penyakit sistemik yang bermanifestasi di rongga mulut dengan diagnosis dini, pencegahan, dan manajemen yang efektif untuk penyakit sistemik. Upaya untuk mencapai indikator tersebut belum optimal, dilihat dari data indeks karies anak usia 12 tahun di Indonesia tahun 2003 berkisar 2,2. ${ }^{6}$ Prevalensi karies anak di Palembang tahun 2005 sebesar $92,43 \%{ }^{7}$
Pencegahan yang dilakukan sejak awal dapat meminimalkan biaya perawatan. Salah satu strategi pencegahan penyakit gigi adalah mengenali faktor risiko penyakit gigi. Mengetahui penilaian tingkat risiko karies dan membedakan tindakan pencegahan yang diberikan pada setiap tindakan dianggap perlu karena semua anak mempunyai risiko terkena karies. ${ }^{9,10}$

Penelitian ini bertujuan untuk mengetahui seberapa besar prediksi risiko karies baru pada anak usia 11-12 tahun di Palembang dan seberapa besar kontribusi pempek dalam mempengaruhi terjadinya karies baru serta bagaimana urutan prediksi risiko karies di Palembang berdasarkan cariogram.

\section{METODE PENELITIAN}

Penelitian ini mendapatkan persetujuan etichal clearence dari komite etik FKG UGM, merupakan penelitian observasional dengan desain cross sectional. Populasi penelitian ini adalah semua siswa yang berusia 11-12 tahun, berdomisili minimal 5 tahun di Palembang dari 268 SD untuk menggambarkan Palembang secara keseluruhan. Subjek penelitian diambil secara cluster sampling, sebanyak 305 orang dari 52 SD. Setiap subjek yang menjadi sampel mendapat perlakuan yang sama dengan informed consent sebelum penelitian. Pengukuran cariogram dengan mengukur kapasitas buffer saliva (dilakukan pengukuran setelah saliva terkumpul menggunakan $\mathrm{pH}$ meter), volume saliva (diambil tanpa dirangsang, dihitung dengan cara membagi hasil yang didapat dengan waktu untuk mengumpulkan saliva), plak skor (menggunakan Personal hygiene performance-modified (PHPM), Decay missing filling-tooth (DMF-T), survei frekuensi makan dan frekuensi makan pempek sehari-hari selama 24 jam (dilakukan 3 kali berselang hari untuk melihat kebiasaan anak), program fluor dan penyakit umum yang diderita. ${ }^{11}$ Hasil pengukuran 7 komponen tersebut diberi skor untuk dimasukkan ke dalam program cariogram, makin tinggi skor makin jelek keadaannya (skor 0-3). Program cariogram dapat mengekspresikan 


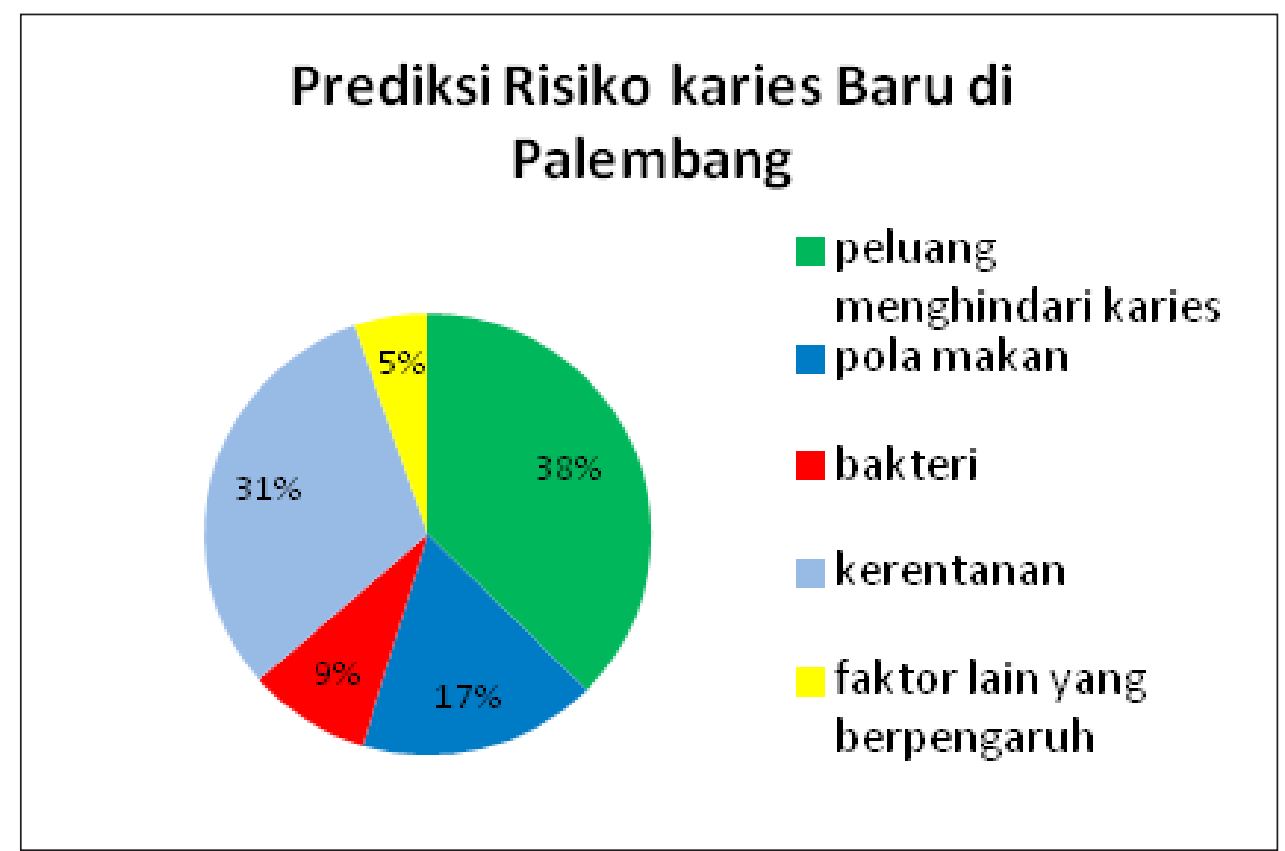

Gambar 1. Cariogram prediksi risiko karies baru di Palembang

Tabel 1. Hasil analisis cariogram faktor penyebab terjadinya karies baru pada anak usia 11-12 tahun berdasarkan frekuensi konsumsi makan keseluruhan dan frekuensi konsumsi makan pempek

\begin{tabular}{lll}
\hline Analisis Cariogram & \multicolumn{1}{c}{$\begin{array}{c}\text { Frekuensi makan keseluruhan } \\
(\mathbf{X} \pm \mathbf{S d})\end{array}$} & $\begin{array}{c}\text { Frekuensi makan } \\
\text { pempek (XISd) }\end{array}$ \\
\hline Peluang menghindari karies baru & $34,2 \pm 22,4$ & $48,4 \pm 21,8$ \\
Pola makan (2) & $17,4 \pm 8,9$ & $8,7 \pm 2,7$ \\
Bakteri (3) & $9,0 \pm 2,7$ & $8,1 \pm 2,3$ \\
Kerentanan (1) & $31,0 \pm 21,4$ & $30,0 \pm 22,1$ \\
Keadaan lain yang berpenga ruh (4) & $5,4 \pm 4,0$ & $5,0 \pm 3,3$ \\
\hline
\end{tabular}

seberapa peluang menghindari karies dan urutan prediksi risiko yang menjadi penyebab. Penilaian tinggi rendahnya risiko diketahui berdasarkan hasil pengurangan $100 \%$ dengan peluang menghindari karies. ${ }^{4}$

\section{HASIL PENELITIAN}

Hasil penelitian menunjukkan dari 305 responden yang diteliti, 171 responden berjenis kelamin perempuan, 134 responden berjenis kelamin laki-laki. Rerata kapasitas buffer saliva 6,7 , rerata sekresi saliva $0,3 \mathrm{ml} / \mathrm{menit}$, rerata plak skor.5, rerata DMF-T 3,42, rerata frekuensi makan 7 kali per hari, rerata frekuensi konsumsi pempek 2 kali per hari, rerata program fluor hanya dari sikat gigi tidak ada yang menderita penyakit sistemik.
Pempek memberikan kontribusi $51,5 \%$ dari total konsumsi keseluruhan.

Hasil prediksi risiko karies baru berdasarkan cariogram menunjukkan rerata prediksi risiko karies baru pada anak usia 11-12 tahun di Palembang sebesar $65,72 \%$ dengan kategori tinggi, urutan prediksi risiko kerentanan, pola makan, bakteri dan faktor lain yang berpengaruh (Gambar 1). Prediksi risiko karies baru pada 305 anak dengan frekuensi konsumsi pempek dapat di lihat pada Tabel 1.

\section{PEMBAHASAN}

Pempek merupakan jajanan yang terbuat dari sagu, memiliki tekstur yang kenyal, biasa dimakan bersama cuko (kuah asam manis/pedas). Cuko 
mengandung fluor, kalsium $\left(\mathrm{Ca}^{2+}\right)$ dan phosphat $\left(\mathrm{PO}_{4}\right){ }^{12}$ Pengunyahan pempek dan rasa asam manis atau pedas dari cuko dapat merangsang kelenjar saliva secara mekanis dan kimia untuk mensekresi saliva lebih banyak.

Sekresi saliva yang banyak menaikkan $\mathrm{pH}$ saliva, kapasitas buffer saliva meningkat, fungsi buffer menetralkan asam, sehingga demineralisasi dapat dicegah. ${ }^{15}$ Hasil analisis cariogram prediksi risiko karies di Palembang sebesar 65,72\% (100\%-peluang menghindari karies) dengan kategori tinggi, frekuensi pempek memberi kontribusi 51,5\% (100\%-peluang menghindari karies dari cariogram pempek) dari total konsumsi makan keseluruhan, urutan prediksi risiko kerentanan, pola makan, bakteri dan faktor lain yang berpengaruh.

Kerentanan merupakan faktor risiko yang didapat dari kombinasi data DMF-T, program fluor, volume sekresi saliva dan kapasitas buffer saliva. Data penelitian diketahui anak-anak yang menjadi responden dengan rerata DMF-T 3,42, tidak mendapatkan program fluor secara optimal, hanya melakukan sikat gigi dengan pasta gigi yang mengandung fluor, dilakukan sebanyak 2 kali sehari pada waktu mandi pagi dan sore (tidak sesuai anjuran), data dari Balai tekhnik kesehatan lingkungan (BTKL) Palembang (2013) kadar fluor sumber air minum (PDAM) di Palembang berkisar $0,003-0,009 \mathrm{ppm}$, rerata sekresi saliva responden $0,3 \mathrm{ml} / \mathrm{menit}$ dengan kategori rendah

Sisa makanan yang dibiarkan tinggal lama tanpa dibersihkan menyebabkan proses metabolisme karbohidrat oleh bakteri menjadi asam dengan hasil samping asam laktat diikuti buffer saliva tidak berfungsi dengan baik (sekresi rendah) dan terjadi proses demineralisasi, dimulai dengan kerusakan jaringan keras kemudian diikuti kerusakan jaringan organik (gigi yang rentan tidak mendapatkan fluor yang maksimal) terjadi karies.

Urutan prediksi yang kedua adalah pola makan, data yang dikumpulkan berupa hasil survey diet responden selama 24 jam (melihat kebiasaan dilakukan survey diet selama 3 kali seminggu), hasilnya menunjukkan rerata frekuensi konsumsi makan responden tinggi yaitu 6-7 kali sehari. Hasil
Uji beda frekuensi konsumsi pempek dan prediksi risiko karies $p<0,005$. Hubungan risiko karies dengan makanan berkaitan dengan frekuensi asupan karbohidrat dan waktu paparan yang lama dapat menyebabkan fermentasi karbohidrat dalam mulut menjadi tinggi. Peningkatan frekuensi makan seseorang akan berdampak pada paparan asam menjadi lama, apabila seseorang mengkonsumsi karbohidrat menyebabkan $\mathrm{pH}$ kritis $(5,5)$ selama 40 menit, bila mengkonsumsi 5 kali menyebabkan paparan asam 200 menit (5 kali makan x 40 menit $=200$ menit). ${ }^{16,14}$

Bakteri menjadi urutan prediksi yang ketiga. Penilaian bakteri diambil dari banyaknya plak. Hasil penelitian menunjukkan rerata skor plak 5,0 dengan kategori baik. Hal ini dikarenakan kebiasaan anak mengkonsumsi pempek lebih dari 2 kali setiap hari (sarapan pagi, jajan di sekolah dan sore hari). Efek pengunyahan pempek yang sifatnya kenyal dan asam dari cuko merangsang mekanisme kelenjar saliva untuk sekresi saliva. Secara mekanisme pengunyahan dapat membantu membersihkan sisa-sisa makanan

Frekuensi konsumsi pempek secara keseluruhan menyumbang $51,5 \%$ dari total konsumsi makan keseluruhan. Berdasarkan data penelitian rerata responden mengkonsumsi pempek 1-4 kali sehari. Pempek dan cuko merupakan makanan yang mengandung karbohidrat jenis polisakarida (sagu) dan disakarida (sukrosa dari gula merah/gula jawa). Perilaku mengkonsumsi makanan dipengaruhi oleh beberapa faktor antara lain sejumlah faktor budaya, sosioekonomi dan faktor lingkungan disamping karakteristik pribadi misalnya pengetahuan. ${ }^{15}$ Seseorang dengan frekuensi makan karbohidrat (sukrosa) lebih dari 3 kali diantara waktu makan dengan jenis yang lengket secara berlebihan dapat meningkatkan aktifitas bakteri yang mengakibatkan $\mathrm{pH}$ dalam mulut rendah sehingga terjadi demineralisasi.

Penelitian ini sejalan dengan penelitian Budisuari ${ }^{15}$ yang menyatakan seseorang yang sering mengkonsumsi makanan yang mengandung sukrosa dan tidak diikuti dengan kebiasaan menyikat gigi yang baik dapat mempengaruhi berat 
ringannya karies. Penelitian Hysi ${ }^{16}$ dan kawankawan juga menyatakan bahwa tingginya DMF-T anak usia 12 tahun di Tirana Albania disebabkan karena kebiasaan konsumsi karbohidrat yang tinggi tidak diikuti frekuensi menyikat gigi yang tinggi juga.

\section{KESIMPULAN}

Prediksi risiko karies anak usia 11-12 tahun di Palembang sebesar $65,72 \%$, termasuk dalam kategori tinggi. Pempek memberikan kontribusi $51,5 \%$ dari total frekuensi makan keseluruhan. Semakin sering anak mengkonsumsi pempek semakin tinggi prediksi risiko terjadinya karies baru. Urutan prediksi risiko karies adalah kerentanan, pola makan, bakteri dan faktor lain yang berpengaruh

Penelitian ini dapat dijadikan acuan bagi Instansi Kesehatan khususnya di Kotamadya Palembang dalam melaksanakan usaha promotif dan preventif, guna menurunkan prevalensi karies di Palembang

\section{DAFTAR PUSTAKA}

1. Camassimo PS, Hendry WF, Dennis JM, Arthur JN. Pediatric dentistry infancy through adolescence Sunders: Elsevier. 2013; 149199.

2. Richmond S, Chesnutt I, Shennan J, Brown $R$. The relationship of medical and dental factors to perceived general and dental health. Community Dent Oral Epidemiol. 2007; 35: 89-97.

3. Kidd EAM.. Essentials of dental caries. $3^{\text {th }}$ ed. Oxford: Oxford University Press; 2005. Press. 2005; h.3-11

4. Bratthal D, Petersson HG, Jr Stjernward. Cariogram Manual internet version 2004, Sweden, Förlagshuset Gothia, Stockholm. 2004.

5. Robert SH, Amid I, dan Nigel PB. Dental caries. The Lancet. 2007; 369: 51-59

6. Trikarjana P. Kontroversi penyakit karies gigi dan distribusi tablet fluor di kota Palembang. JKK Unsri. 2005; 37 (3): 1067-1072.
7. Kemenkes RI. Perencanaan Program Kesehatan Gigi dan Mulut 2011-2025, Kemenkes RI, Jakarta, 2010

8. Wahyuni S, Puspitasari D, Mujiati. Prevalensi Karies Gigi Pada Siswa-Siswi Sekolah Dasar Negeri di Kotamadya Palembang. JKK Unsri. 2008; 40 (2): 2093-2096.

9. Angela A. Pencegahan primer pada anak yang beresiko karies tinggi (primary prevention in children with high caries risk ). Dent J. 2005; 38 (3): 130-134

10. Katsumura S, Nishikawara F, Tamaki $Y$, Yamada H, Nakamura $Y$, Sato K, Tsuge S, Nomura $Y$, Hanada N. Evaluation of risk factors for dental caries from 6 to 8 years old children. J Paediatr Dent. 2008;18(1): 27-33.

11. Pintauli $\mathrm{S}$, Hamada T. Menuju gigi dan mulut sehat (pencegahan dan pemeliharaan). Medan: USU Press. 2008: 4-27.

12. Rahardjo TBW. Hubungan erosi gigi dengan kebiasaan makan pempek di palembang Sumatera Selatan. Disertasi. Surabaya: UNAIR; 1989

13. Stegeman CA, Judi RD. The dental hygienist's guide to nutritional care, Saunders: Elseiver; 2005. 404-411

14. Mobley C, Marshall TA, Milgrom P, Coldwell SE. The contribution of dietary factors to dental caries and disparities in caries. Acad Pediatr. 2009; 9 (6): 410-414.

15. Budisuari MA, Oktarina M, Agus M. Hubungan pola makan dan kebiasaan menyikat gigi dengan kesehatan gigi dan mulut (karies) di Indonesia. Buletin Penelitian Sistem Kesehatan. 2010; 13 (1): 83-91.

16. Hysi D, Droboniku E, Toti C, Xhemnica L, Petrella E. Dental caries experience and oral health behaviour among 12-year-old in the city of tirana albania. OHDMBSC. 2010; IX(4): 229-234. 